\title{
PERBANDINGAN EFEKTIFITAS PEMBERIAN KOMPRES HANGAT DAN TEPIDSPONGE TERHADAP PENURUNAN SUHU TUBUH ANAK YANG MENGALAMIDEMAM RSUD dr. H. ABDUL MOELOEK PROVINSI LAMPUNG
}

\author{
Aryanti Wardiyah $^{1}$, Setiawati ${ }^{2}$, Dwi Setiawan ${ }^{3}$ \\ ${ }^{1,2}$ Akademi Keperawatan Malahayati Bandarlampung \\ ${ }^{3}$ Mahasiswa Akademi Keperawatan Malahayati Bandarlampung
}

\begin{abstract}
ABSTRAK
Demam dapat berdampak kejang dan penurunan kesadaran. Data rekam medik RSUD dr. H. Abdul Moeloek Provinsi Lampung tahun 2014 jumlah anak yang menderita demam dengan bronkopneumonia 442 anak, typhoid 279 anak dan DHF 46 anak. Tujuan penelitian untuk mengetahui perbandingan efektifitas pemberian kompres hangat dan tepid sponge terhadap penurunan suhu tubuh anak yang mengalami demam diruang Alamanda. Jenis penelitian kuantitatif, desain quasi eksperiment dengan rancangan penelitian pre test andpost test designs with two comparison treatments. Populasi adalah anakyang mengalami demam dengan penyakit bronkopnuemonia, typhoid, dan DHF yang berjumlah 185 anak. Sampel dibagi 2 kelompok masing-masing 15 orang, yang diambil dengan teknik purposive sampling. Analisis menggunakan univariat dan bivariat dengan uji T dependen dan uji T independen. Hasil uji statistik menunjukkan ada perbedaan penurunan suhu tubuh antara kompres hangat dengan mean $0,5{ }^{\circ} \mathrm{C}$ dan tepid sponge dengan mean $0,8^{\circ} \mathrm{C}$ ( $p$ value $<\alpha, 0,003<0,05$ ). Saran untuk Rumah Sakit hasil penelitian ini dapat dijadikan masukan untuk standar operasional prosedur dalam menurunkan suhu tubuh anak yang mengalami demam secara non farmakologis.
\end{abstract}

Kata kunci : Kompres hangat, tepid sponge, demam

\begin{abstract}
Impact of fever for the child until stiff and lost consciousness. Medical record dr. H. Abdul Moeloek Lampung Province in 2014 the number of children who has fever with bronchopneumonias were 442 , typhoids were 279, and DHF were 46 children. Purpose of this study was to compare the effectiveness of warm compress and tepid sponge to decrease the body temperature of children who have a fever in Alamanda room. This quantitative research, quasi experiment design with pretest research design and post test designs with two comparison treatments. The population were a children who has a fever with bronchopneumonia disease, typhoid, and DHF amounts to 185 children. Samples were divided into two groups that consist of 15 people, taken by purposive sampling technique. The analysis is using the analysis of univariate and bivariate with dependent $T$ test and independent $T$ test. Results of statistical showed the difference of temperature decrease between the body temperature warm compress with a mean of $0.5^{\circ} \mathrm{C}$ and tepid sponge with a mean of $0.8^{\circ} \mathrm{C}$ ( $p$ value $\left.<\alpha, 0.003<0.05\right)$. The Advice to Hospital related to the result of this study can be used as input to the standard operating procedures in decreasing the fever of children who have a fever in non-pharmacologic.
\end{abstract}

Key words :Warm compress, tepid sponge, fever

Jurnal IImu Keperawatan, Vol: 4, No.1, Mei 2016; Korespondensi: Aryanti Wardiyah Akademi Keperawatan Malahayati Bandarlampung. Jl. Pramuka no.27 Kemiling Bandarlampung. Email: gipho85@yahoo.com. No. HP: 081328291685 


\section{PENDAHULUAN}

Demam merupakan suatu keadaan suhu tubuh diatas normal sebagai akibat peningkatan pusat pengatur suhu di hipotalamus (Sodikin, 2012).Sebagian besar demam pada anak merupakan akibat dari perubahan pada pusat panas (termoregulasi) di hipotalamus.Penyakit - penyakit yang ditandai dengan adanya demam dapat menyerang sistem tubuh.Selain itu demam mungkin berperan dalam meningkatkan perkembangan imunitas spesifik dan nonspesifik dalam membantu pemulihan atau pertahanan terhadap infeksi (Sodikin, 2012).Badan Kesehatan Dunia (WHO) memperkirakan jumlah kasus demam di seluruh Dunia mencapai 16 - 33 juta dengan 500 - 600 ribu kematian tiap tahunnya (Setyowati, 2013). Data kunjungan ke fasilitas kesehatan pediatrik di Brazil terdapat sekitar 19\% sampai $30 \%$ anak diperiksa karena menderita demam. Penelitian oleh Jalil, Jumah, dan Al-Baghli (2007), di Kuwait menunjukkan bahwa sebagian besar anak usia tiga bulan sampai 36 bulan mengalami serangan demam rata-rata enam kali pertahunnya (Setiawati, 2009).

Di Indonesia penderita demam sebanyak 465 (91.0\%) dari 511 ibu yang memakai perabaan untuk menilai demam pada anak mereka sedangkan sisanya 23,1 saja menggunakan thermometer (Setyowati, 2013). Data Dinas Kesehatan Provinsi Lampung tahun 2013 menyebutkan bahwa demam pada anak usia 114 tahun mencapai 4.074 anak dengan klasifikasi 1.837 anak pada usia 1-4 tahun, 1.192 anak pada usia 5-9 tahun dan 1.045 anak pada usia 10-14 tahun. Penyakit terbanyak dengan gejala awal demam di ruang Alamanda RSUD dr. H. Abdul Moeloek pada tahun 2014 yaitu Bronkopneumonia, Demam Typhoid dan DHF. Anak yang menderita demam dengan penyakit Bronkopneumonia mencapai 442 anak, Demam Typhoid mencapai 279 anak dan DHF mencapai 46 anak.

Demam pada anak dibutuhkan perlakuan dan penanganan tersendiri yang berbeda bila dibandingkan dengan orang dewasa. Hal ini dikarenakan, apabila tindakan dalam mengatasi demam tidak tepat dan lambat maka akan mengakibatkan pertumbuhan dan perkembangan anak terganggu. Demam dapat membahayakan keselamatan anak jika tidak ditangani dengan cepat dan tepat akan menimbulkan komplikasi lain seperti, hipertermi, kejang dan penurunan kesadaran (Maharani, 2011). Demam yang mencapai suhu $41^{\circ} \mathrm{C}$ angka kematiannya mencapai $17 \%$, dan pada suhu $43^{\circ} \mathrm{C}$ akan koma dengan kematian $70 \%$, dan pada suhu $45^{\circ} \mathrm{C}$ akan meninggal dalam beberapa jam (Said, 2014).

Penanganan terhadap demam dapat dilakukan dengan tindakan farmakologis, tindakan non farmakologis maupun kombinasi keduanya 
.Tindakan farmakologis yaitu memberikan obat antipiretik.Sedangkan tindakan non farmakologis yaitu tindakan tambahan dalam menurunkan panas setelah pemberian obat antipiretik.Tindakan non farmakologis terhadap penurunan panas seperti memberikan minuman yang banyak, ditempatkan dalam ruangan bersuhu normal, menggunakan pakaian yang tidak tebal, dan memberikan kompres (Kania, 2007).

Kompres hangat adalah tindakan denganmenggunakan kain atau handuk yang telah dicelupkan pada air hangat, yang ditempelkan pada bagian tubuh tertentu sehingga dapat memberikan rasa nyaman dan menurunkan suhu tubuh (Maharani, 2011). Hasil penelitian yang dilakukan oleh Wahyuni (2009), di RSUP DR Wahidin Sudirohusodo Makassar menunjukkan bahwa pemberian kompres hangat pada daerah aksila dan dahi mempunyai efek dalam menurunan suhu tubuh pada klien demam. Penurunan suhu tubuh klien yang dikompres air hangat di daerah aksila rata-rata $0,0933^{\circ} \mathrm{C}$ sedangkan penurunan suhu tubuh klien yang dikompres air hangat di daerah dahi rata-rata $0,0378^{\circ} \mathrm{C}$.

Tindakan lain yang digunakan untuk menurunkan panas adalah tepid sponge. Tepid sponge merupakan suatu proseduruntuk meningkatkan kontrol kehilangan panas tubuh melalui evaporasi dan konduksi, yang biasanya dilakukan pada pasien yang mengalami demam tinggi.Tujuan dilakukan tindakan tepid sponge yaitu untuk menurunkan suhu tubuh pada pasien yang mengalami hipertermia (Hidayati, 2014).

Hasil penelitian yang dilakukan oleh Setiawati (2009), pada anak usia prasekolah dan sekolah yang mengalami demam di ruang perawatan anak Rumah Sakit Muhammadiyah Bandung menunjukkan bahwa pemberian antipiretik yang disertai tepid sponge mengalami penurunan suhu yang lebih besar jika dibandingkan dengan pemberian antipiretik saja.

Berdasarkan hasil wawancara yang dilakukan peneliti tanggal 27 Januari kepada perawat yang berada di ruang Alamanda didapatkan bahwa terapi yang digunakan dalam menangani demam pada anak diruangan tersebut yaitu menggunakan terapi farmakologis dan terapi non farmakologis.Terapi farmakologis yang digunakan yaitu obat antipiretik sedangkan terapi non farmakologis yang sering digunakan diruang tersebut yaitu kompres hangat dan tepid sponge.Namun belum pernah dilakukan penelitian terkait keefektifan kedua tindakan tersebut.

Tujuan umum penelitian ini yaitu untuk mengetahui perbandingan efektifitas pemberian kompres hangat dan tepidsponge terhadap penurunan suhu tubuhanak yang 
mengalami demam. sedangkan tujuan khusus penelitian ini antara lain untuk mengetahui karakteristik responden berdasarkan usia, mengetahui rerata suhu tubuh anak sebelum dilakukan pemberian kompres hangat, untuk mengetahui rerata suhu tubuh anak sesudah dilakukan pemberian kompres hangat, untuk mengetahui rerata suhu tubuh anak sebelum dilakukan tepidsponge, untuk mengetahui rerata suhutubuh anak sesudah dilakukan tepid sponge, untuk mengetahui perbedaan suhu tubuh sebelum dan sesudah dilakukan kompres hangat, untuk mengetahui perbedaan suhu tubuh sebelum dan sesudah dilakukan tepidsponge, dan untuk mengetahuiperbandingan efektifitas pemberian kompres hangat dan tepid sponge terhadap penurunan suhu tubuh pada anak yang mengalami demam.

\section{METODE}

Desain penelitian ini adalah quasieksperiment dengan rancangan penelitian pre test and post test designs with two comparison treatments. Rancangan penelitian ini,kedua kelompok diberikan perlakuan dan peneliti mengukur suhu tubuh sebelum pemberian perlakuan (pre test), dan setelah pemberian perlakuan (post test).

Penelitian ini dilaksanakan di Ruang Alamanda RSUD dr. H. Abdul Moeloek Provinsi Lampung, mulai tanggal 07 April sampai 07 Mei 2015.
Populasi adalah semua anak yang mengalami demam dengan penyakit bronkopneumonia, demam typhoid, dan DHF dari bulan November sampai Desember yang dirawat di Ruang Alamanda berjumlah 185 anak. Pengambilan sampel menggunakan teknik purposive sampling sebanyak 30 orang terdiri dari 15 orang sebagai kelompok kompres hangat dan 15 orang sebagai kelompok tepid sponge.

Analisa pada penelitian ini menggunakan dua uji hipotesa yaitu Dependent $T$ test dan Independent $T$ test karena data berdistribusinormal setelah dilakukan uji kenormalan dengan shapiro wilk dengan hasil $p$ value $>0,05$

HASIL

\section{Distribusi Frekuensi Karakteristik Responden Berdasarkan Usia}

Tabel 1. Distribusi Frekuensi Karakteristik Responden Berdasarkan Usia Di Ruang Alamanda

\begin{tabular}{rll}
\hline Umur & Frekuensi & Persentase (\%) \\
\hline 1 tahun & 1 & 3.3 \\
2 tahun & 9 & 30.0 \\
3 tahun & 7 & 23.3 \\
4 tahun & 9 & 30.0 \\
5 tahun & 4 & 13.3 \\
\hline Total & 30 & 100.0 \\
\hline
\end{tabular}

Tabel 1 menunjukkan bahwa distribusi frekuensi karakteristik responden berdasarkan usia diruang Alamanda RSUD dr. H. Abdul Moeloek Provinsi Lampung tahun 2015, usia yang paling banyak menjadi responden yaitu pada usia 2 tahun sebanyak 9 orang (30.0\%) dan pada usia 4 tahun sebanyak 9 orang 
(30.0\%).

Rerata Suhu Tubuh Sebelum dan sesudah Dilakukan Kompres Hangat

Tabel 2. Rerata Suhu Tubuh Sebelum dan sesudah Dilakukan Kompres Hangat Di Ruang Alamanda

\begin{tabular}{lllll}
\hline Variabel & $\begin{array}{l}\text { Mean } \\
\left({ }^{\circ} \mathrm{C}\right)\end{array}$ & $\begin{array}{l}\text { Std. } \\
\text { Deviation }\end{array}$ & $\begin{array}{l}\text { Min } \\
\left({ }^{\circ} \mathrm{C}\right)\end{array}$ & $\begin{array}{l}\text { Max } \\
\left({ }^{\circ} \mathrm{C}\right)\end{array}$ \\
\hline $\begin{array}{l}\text { Suhu } \\
\text { tubuh } \\
\text { sebelum }\end{array}$ & 38,5 & 0,6638 & 37,7 & 39,5 \\
tindakan & & & & \\
kompres & & & & \\
hangat & & & & \\
\hline $\begin{array}{l}\text { Suhu } \\
\text { tubuh } \\
\text { sesudah } \\
\text { tindakan }\end{array}$ & 38 & 0,5506 & 37,2 & 38,9 \\
kompres & & & & \\
hangat & & & & \\
\hline
\end{tabular}

Tabel 2 menunjukkan rerata suhu tubuh sebelum diberi tindakan kompres hangat adalah $38,5^{\circ} \mathrm{C}$. sedangkan rerata suhu sesudah diberikan kompres hangat adalah $38,0^{\circ} \mathrm{C}$. Sehingga ada penurunan sebesar $0,5^{\circ} \mathrm{C}$.

Rerata Suhu Tubuh Sebelum dan sesudah Dilakukantepid sponge

Tabel 3. Rerata Suhu Tubuh Sebelum dan sesudah Dilakukan TepidSponge Di Ruang Alamanda

\begin{tabular}{|c|c|c|c|c|}
\hline Variabel & $\begin{array}{l}\text { Mean } \\
\left({ }^{\circ} \mathrm{C}\right)\end{array}$ & $\begin{array}{l}\text { Std. } \\
\text { Deviation }\end{array}$ & $\begin{array}{l}\text { Min } \\
\left({ }^{\circ} \mathrm{C}\right)\end{array}$ & $\begin{array}{l}\text { Max } \\
\left({ }^{\circ} \mathrm{C}\right)\end{array}$ \\
\hline $\begin{array}{l}\text { Suhu } \\
\text { tubuh } \\
\text { sebelum } \\
\text { tindakan }\end{array}$ & 38,8 & 0,6026 & 38,1 & 40,5 \\
\hline $\begin{array}{l}\text { Tepid } \\
\text { Sponge }\end{array}$ & & & & \\
\hline $\begin{array}{l}\text { Suhu } \\
\text { tubuh } \\
\text { sesudah } \\
\text { tindakan } \\
\text { Tepid } \\
\text { Sponge }\end{array}$ & 38 & 0,5663 & 37,4 & 39,3 \\
\hline
\end{tabular}

Tabel 3 menunjukkan bahwa rerata (mean) suhu tubuh sebelum diberi tindakan tepid sponge adalah $38,8^{\circ} \mathrm{C}$ sedangkan sesudah tindakan tepid sponge adalah $38,0^{\circ} \mathrm{C}$, sehingga terdapat penurunan sebesar $0,7^{\circ} \mathrm{C}$.

\section{Perbedaan Suhu Tubuh Sebelum Dan}

\section{Sesudah Dilakukan Kompres Hangat}

Tabel 4. Perbedaan Suhu Tubuh Sebelum Dan Sesudah Dilakukan Kompres Hangat Di

Ruang Alamanda

\begin{tabular}{|c|c|c|c|c|c|c|c|}
\hline Variabel & $\begin{array}{c}\text { Mean } \\
\left({ }^{\circ} \mathrm{C}\right)\end{array}$ & SD & $\begin{array}{c}\text { Mean } \\
\text { Differen } \\
\text { ce }\left({ }^{\circ} \mathrm{C}\right)\end{array}$ & $\begin{array}{c}\text { SD } \\
\text { Differe } \\
\text { nce }\end{array}$ & $\begin{array}{c}\text { SE } \\
\text { Mean } \\
\text { differen } \\
\text { ce }\end{array}$ & $\begin{array}{c}\text { P- } \\
\text { Value }\end{array}$ & $\overline{\mathbf{N}}$ \\
\hline $\begin{array}{l}\text { Suhu } \\
\text { Tubuh } \\
\text { Sebelum } \\
\text { Tindakan } \\
\text { Kompres } \\
\text { hangat }\end{array}$ & 38,5 & 0,6638 & & & & & \\
\hline $\begin{array}{l}\text { Suhu } \\
\text { Tubuh } \\
\text { Sesudah } \\
\text { Tindakan } \\
\text { Kompres } \\
\text { hangat }\end{array}$ & 38 & 0,5506 & 0,5133 & 0,2475 & 0,0639 & 0,000 & 15 \\
\hline
\end{tabular}

Tabel 4 menunjukkan bahwa nilai $p$ value $=$

0,000 pada alpha 5\% maka dapat disimpulkan ada perbedaan rerata (mean) suhu tubuh sebelum dan sesudah tindakan kompres hangat.

\section{Perbedaan Suhu Tubuh Sebelum Dan Sesudah}

\section{Dilakukan Tepid Sponge}

Tabel 5. Perbedaan Suhu Tubuh Sebelum Dan Sesudah Dilakukan Tepid Sponge Di Ruang Alamanda

\begin{tabular}{|c|c|c|c|c|c|c|c|}
\hline Variabel & $\begin{array}{c}\text { Mean } \\
\left({ }^{\circ} \mathrm{C}\right)\end{array}$ & SD & $\begin{array}{c}\text { Mean } \\
\text { differen } \\
\text { ce }\left({ }^{\circ} \mathrm{C}\right)\end{array}$ & $\begin{array}{c}\text { SD } \\
\text { differen } \\
\text { ce }\end{array}$ & $\begin{array}{c}\text { SE } \\
\text { Mean } \\
\text { Differe } \\
\text { nce }\end{array}$ & $\begin{array}{c}\text { P- } \\
\text { Value }\end{array}$ & $\mathbf{N}$ \\
\hline $\begin{array}{l}\text { Suhu tubuh } \\
\text { sebelum } \\
\text { tepid } \\
\text { sponge }\end{array}$ & 38,8 & 0,6026 & & & & & \\
\hline $\begin{array}{l}\text { Suhu tubuh } \\
\text { sesudah } \\
\text { Tepid } \\
\text { Sponge }\end{array}$ & 38 & 0,5663 & 0,7867 & 0,2200 & 0,0568 & 0,000 & 15 \\
\hline
\end{tabular}


Tabel 5menunjukkan bahwa nilai $p$ value $=0,000$ pada alpha $5 \%$ maka dapat disimpulkan ada perbedaan rerata (mean) suhu tubuh sebelum dan sesudah tindakan tepid sponge.

\section{Perbandingan Pemberian Kompres Hangat Dan Tepid Sponge Terhadapm Penurunan Suhu Tubuh}

Tabel 6. Perbandingan Pemberian Kompres Hangat Dan Tepid Sponge Terhadap Penurunan Suhu Tubuh Di Ruang Alamanda

\begin{tabular}{|c|c|c|c|c|c|c|}
\hline Variabel & $\begin{array}{c}\text { Mean } \\
\left({ }^{\circ} \mathrm{C}\right)\end{array}$ & SD & $\begin{array}{c}\text { Mean } \\
\text { difference } \\
\left({ }^{\circ} \mathrm{C}\right)\end{array}$ & $\begin{array}{c}\text { SE Mean } \\
\text { Differenc } \\
\mathrm{e} \\
\end{array}$ & P-Value & $\mathbf{N}$ \\
\hline $\begin{array}{c}\text { Suhu } \\
\text { tubuh } \\
\text { Kompres } \\
\text { Hangat }\end{array}$ & 0,5 & 0,2475 & \multirow{2}{*}{-.2733} & \multirow{2}{*}{0,0855} & \multirow{2}{*}{0,003} & \multirow{2}{*}{30} \\
\hline $\begin{array}{l}\text { Suhu } \\
\text { tubuh } \\
\text { Tepid } \\
\text { Sponge }\end{array}$ & 0,7 & 0,2200 & & & & \\
\hline
\end{tabular}

Tabel 6 menunjukkan rerata penurunan suhu tubuh setelah pemberian kompres hangat sebesar $0,5^{\circ} \mathrm{C}$ sedangkan rerata penurunan suhu tubuh setelah pemberian tepid sponge sebesar $0,7^{\circ} \mathrm{C}$. Hasil uji statistik Independent Sample TTest didapatkan nilai $p$ value $=0,003$ padaalpha 5\% maka dapat disimpulkan ada perbedaan efektifitas penurunan suhu tubuh pada kompres hangat dan Tepid sponge.

\section{PEMBAHASAN}

\section{Distribusi Frekuensi Karakteristik Responden}

\section{Berdasarkan Usia}

Hasil penelitian menunjukkan usia yang paling banyak menjadi responden yaitu pada usia 2 tahun sebanyak 9 orang (30.0\%) dan pada usia 4 tahun sebanyak 9 orang (30.0\%). Hasil ini sangat wajar apabila yang menjadi sampel pada penelitian ini kebanyakan masih balita, karena memang pada balita belum terjadi kematangan pada mekanisme pengaturan suhu, inilah yang menyebabkan pada usia balita sangat rentan terserang penyakit termasuk demam. Selain itu juga pada usia balita masih sangat sensitif terhadap perubahan suhu lingkungan.

\section{Rerata Suhu Tubuh Sebelum dan sesudah Dilakukan Kompres Hangat}

Berdasarkan tabel 2 dapat diketahui rerata (mean) suhu tubuh sebelumdiberi tindakan kompres hangat adalah $38,5^{\circ} \mathrm{C}$, dan sesudah kompres hangat sebesar $38,0^{\circ} \mathrm{C}$.

Semua penyakit yang diderita oleh respoden disebabkan oleh infeksi, dan dari proses infeksi inilah yang menyebabkan peningkatan suhu tubuh. Selain itu juga karena usia responden rata - rata masih balita, sangat wajar apabila terjadi peningkatan suhu tubuh apabila responden menderita penyakit infeksi, karena pada usia ini belum terjadi kematangan mekanisme pengaturan suhu tubuh yang menyebabkan tubuh tidak dapat menjaga keseimbangan antara produksi panas dan pengeluaran panas.

Suhu tubuh pada anak yang mengalami demam dipengaruhi proses penyakit yang terjadi pada anak. Pola demam bergantung pada pirogen penyebab. Peningkatan atau penurunan 
aktivitas pirogen mengakibatkan peningkatan dan penurunan demam pada waktu yang berbeda.Durasi dan tingkat demam bergantung pada kekuatan pirogen dan kemampuan respons individu (Potter \& Perry, 2010). Sodikin (2012), menyatakan bahwa apabila anak mengalami demam sebaiknya dilakukan tindakan seperti memberikan kompres hangat, memberikan lingkungan senyaman mungkin, dampingi anak selama demam agar anak merasa aman dan nyaman, berikan mainan yang menjadi kesukaannya, berikan minuman lebih banyak dari biasanya, dan aktivitas fisik yang berat dibatasi.

\section{Rerata Suhu Tubuh Sebelum dan Sesudah Dilakukan tepid sponge}

Berdasarkan tabel 3 dapat diketahui bahwa rerata (mean) suhu tubuh sebelum diberi tindakan tepid sponge adalah $38,8^{\circ} \mathrm{C}$ dengan standar deviasi 0,6026 dan nilai minimum serta maksimumnya adalah $38,1^{\circ} \mathrm{C}$ dan $40,5^{\circ} \mathrm{C}$. Sedangkan rerata (mean) suhu tubuh sesudah diberi tindakan tepid sponge adalah $38,0^{\circ} \mathrm{C}$ dengan standar deviasi 0,5663 dan nilai minimum serta maksimum adalah $37,4^{\circ} \mathrm{C}$ dan $39,3^{\circ} \mathrm{C}$, dengan rerata penurunan suhu sebesar $0,7^{\circ} \mathrm{C}$.

Perbedaan proses penyakit yang terjadi pada masing-masing responden menyebabkan pematokan suhu tubuh yang berbeda antara satu responden dengan responden lainnya
(Guyton \& Hall, 2007). Suhu tubuh pada anak sangat berfluktuasi, hal ini disebabkan termostat pada anak masih belum matur, sehingga mudah berubah dan sensitif terhadap perubahan suhu lingkungan. Termostat anak akan matur saat anak memasuki usia remaja. Seiring dengan pencapaian maturitas tersebut, suhu tubuh akan meningkat dengan variasi suhu $0,54^{\circ} \mathrm{C}$ (Potter \& Perry, 2005).

\section{Perbedaan Suhu Tubuh Sebelum Dan \\ Sesudah Dilakukan Kompres Hangat}

Berdasarkan tabel 4 dapat diketahui bahwa nilai $p$ value $=0,000$ pada alpha $5 \%$ maka dapat disimpulkan ada perbedaan rerata (mean) suhu tubuh sebelum dan sesudah tindakan kompres hangat.

Pemberian kompres hangat memberikan reaksi fisiologis berupa vasodilatasi dari pembuluh darah besar dan meningkatkan evaporasi panas dari pemukaan kulit.Hipotalamus anterior memberikan sinyal kepada kelenjar keringat untuk melepaskan keringat melalui saluran kecil pada permukaan kulit. Keringat akan mengalami evaporasi, sehingga akan terjadi penurunan suhu tubuh (Potter \& Perry, 2010). Hasil ini sejalan dengan hasil penelitian yang dilakukan oleh Purwanti (2008) di RSUD dr. Moewardi Surakarta tentang pengaruh kompres hangat terhadap perubahan suhu tubuh pada pasien anak 
hipertermia,didapatkan hasil $p$ value $=0,001$ yang artinya ada pengaruh kompres hangat terhadap perubahan suhu tubuh pasien anak hipertermi.

Berdasarkan analisa peneliti yang diperkuat oleh penelitian terkait dapat disimpulkan bahwa pemberian kompres hangat dapat menurunkan suhu tubuh pada anak yang mengalami demam. Kompres hangat pada area tubuh akan memberikan sinyal ke hipotalamus melalui sumsum tulang belakang. Ketika reseptor yang peka terhadap panas di hipotalamus dirangsang, sistem afektor mengeluarkan sinyal untuk memulai berkeringat dan vasodilatasi perifer.Perubahan ukuran pembuluh darah diatur oleh pusat vasomotor pada medulla oblongata dari tangkai otak, di bawah pengaruh hipotalamik bagian anterior sehingga terjadi vasodilatasi.Vasodilatasi ini yang menyebabkan pembuangan atau kehilangan panas melalui kulit meningkat sehingga terjadi penurunan suhu tubuh.

\section{Perbedaan Suhu Tubuh Sebelum Dan Sesudah Dilakukan Tepid Sponge}

Berdasarkan tabel 5 dapat diketahui bahwa nilai $p$ value $=0,000$ pada alpha $5 \%$ maka dapat disimpulkan ada perbedaan rerata (mean) suhu tubuh sebelum dan sesudah tindakan tepid sponge.
Pada prinsipnya pemberian tepid sponge dapat menurunkan suhu tubuh melalui proses penguapan dan dapat memperlancar sirkulasi darah, sehingga darah akan mengalir dari organ dalam kepermukaan tubuh dengan membawa panas. Kulit memiliki banyak pembuluh darah, terutama tangan, kaki, dan telinga.Aliran darah melalui kulit dapat mencapai 30\% dari darah yang dipompakan jantung.Kemudian panas berpindah dari darah melaui dinding pembuluh darah kepermukaan kulit dan hilang kelingkungan sehingga terjadi penurunan suhu tubuh (Potter \& Perry, 2010).

Hasil penelitian ini sejalan dengan penelitian yang dilakukan oleh Maling (2012) di RSUD Tugurejo Semarang tentang pengaruh kompres tepid sponge hangat terhadap penurunan suhu tubuh anak umur 1 - 10 tahun dengan hipertermi, didapatkan hasil $p$ value $=0,001$ yang artinya ada pengaruh kompres tepid sponge terhadap penurunan suhu tubuh pada pasien hipertermi.

Hasil penelitian ini sejalan dengan hasil penelitian terkait dimana ada pengaruh pemberian tepid sponge terhadap penurunan suhu tubuh pada anak yang mengalami demam.Tepid sponge dilakukan dengan cara mengelap seluruh tubuh dengan menggunakan washlap lembab hangat selama 15 menit. Efek hangat dari washlap tersebut dapat memvasodilatasi pembuluh darah sehingga 
aliran darah menjadi lancar.Kulit memiliki banyak pembuluh darah, ketika demam panas kemudian diberikan tindakan tepidsponge, panas dari darah berpindah melaluidinding pembuluh darah kepermukaan kulit dan hilang ke luar tubuh.

\section{Perbandingan Pemberian Kompres Hangat} Dan Tepid Sponge Terhadap Penurunan Suhu Tubuh

Berdasarkan tabel 6 dapat diketahui rerata penurunan suhu tubuh setelah pemberian kompres hangat sebesar $0,5^{\circ} \mathrm{C}$ sedangkan rerata penurunan suhu tubuh setelah pemberian tepid sponge sebesar $0,7^{\circ} \mathrm{C}$. Hasil uji statistik Independent Sample TTest didapatkan nilai $p$ value $=0,003$ padaalpha $5 \%$ maka dapat disimpulkan ada perbedaan efektifitas penurunan suhu tubuh pada kompres hangat dan Tepid sponge.

Tepid sponge merupakan suatu proseduryang diberikan kepada pasien dengan tujuan untuk menurunkan atau mengurangi suhu tubuh dengan menggunakan air hangat (Dagoon, et. All, 2007). Seperti pada kompres hangat, tepid sponge bekerja dengan cara mengirimkan implus ke hipotalamus bahwa lingkungan sekitar sedang dalam keadaan panas. Keadaan ini akan mengakibatkan hipotalamus berespon dengan mematok suhu tubuh yang lebih tinggi dengan cara menurunkan produksi dan konservasi panas tubuh (Guyton \& Hall, 2007).

Hasil penelitian ini sejalan dengan penelitian yang dilakukan oleh Isneini (2014) yang berjudul "Efektifitas Penurunan Suhu Tubuh Antara Kompres Hangat Dan Tepid Sponge Pada Pasien Anak Usia 6 Bulan - 3 Tahun Dengan Demam Di Puskesmas Kartasura Kutuharjo" didapatkan hasil bahwa tepidsponge lebih efektif menurunkan suhu tubuh dibandingkan dengan kompres hangat. Tepid sponge lebih efektif menurunkansuhu tubuh anak dengan demam dibandingkan dengan kompres hangat disebabkan adanya seka tubuh pada tepidsponge yang akan mempercepatvasodilatasi pembuluh darah perifer diseluruh tubuh sehingga evaporasi panas dari kulit kelingkungan sekitar akan lebih cepat dibandingkan hasil yang diberikan oleh kompres hangat yang hanya mengandalkan dari stimulasi hipotalamus. Perbedaan luas rasio body surface area dengan jumlah luas washlap yang kontak dengan pembuluh darah perifer yang berbeda antara teknik kompres hangat dan tepid sponge akan turut memberikanperbedaan hasil terhadap percepatan penurunan suhu responden pada kedua kelompok perlakuan tersebut.

Berdasarkan prosedur tindakan, terdapat keunggulan yang dimiliki teknik kompres hangat dibandingkan dengan teknik tepidsponge yaitu kecilnya washlap yang 
kontakdengan tubuh memberikan kenyamanan yang lebih dibandingkan dengan teknik tepid sponge.Ketidaknyamanan ini dapatdilihat dari kegelisahan anak, menangis dan mudah tersinggung. Hal ini sejalan dengan penelitian yang dilakukan oleh Thomas,Vijaykumar, Naik, Moses, dan Antonisamy (2009) yang mengatakan tindakantepidsponge memiliki tingkat ketidaknyamananyang lebih tinggi.

Ketidaknyamanan dapat terjadi karena penularan dari orang tua terhadap anaknya.Bentuk penularan ketidaknyamanan tersebut berupa rasa cemas sebagai respon melihat anak mengalami demam. Hal lain yang dapat menyebabkan ketidaknyamanan pada anak adalah penatalaksanaannya, dimana anak yang mengalami demam diberi tindakan dengan mengelap seluruh bagian tubuh sehingga anak akan merasa gelisah (Setiawati, 2009). Namun seperti yang dijelaskan paragraf

\section{DAFTAR PUSTAKA}

Alves, J. G. B., \& Almedia, Tepid SpongingPlus Dipyrone Versus Dipyrone Alone In Reducing Body Temperature In Febrile Children,Brazil, 2008, diperoleh tanggal 19 Januari 2015, (online) http://www.scielo.br/scielo.php?scr ipt=sci_arttext \&pid=S151631802008000200008

Ambarwati, Fitri R., \& Nita Nasution, BukuPintar Asuhan Keperawatan Bayi \&BalitaCakrawala Ilmu,Yogyakarta, sebelumnya, kombinasi cara kerja tepid sponge lebih unggul menurunkan suhu tubuh pada anak yang demam dibandingkan dengan teknik kompres hangat.

\section{KESIMPULAN}

Hasil penelitian menunjukkan ada perbedaan efektifitas pemberian kompres hangat dan tepid sponge terhadap penurunan suhu tubuh anak yang mengalami demam ( $p$ value $<\alpha$, $0,003<0,05)$. Diharapkan hasil penelitian ini perawat dapat melakukan dan mengajarkan penggunaan kompres hangat dan tepidsponge yang benar pada pasien dan jugadiharapkan hasil penelitian ini dapat digunakan sebagai masukan untuk standar operasional prosedur (SOP) dalam menurunkan suhu tubuh anak yang mengalami demam secara non farmakologis di RSUD dr. H. Abdul Moeloek Provinsi Lampung.

\section{2}

Arief, Z. R., \& Weni K. S., Neonatus DanAsuhan Keperawatan Anak, NuhaOffset, Yogyakarta, 2009

Arikunto, Suharsimi, Prosedur PenelitianSuatu Pendekatan Praktik, RinekaCipta,Jakarta, 2010

Asmadi, Teknik Prosedural Keperawatan Konsep Dan Aplikasi Kebutuhan Dasar Klien, Salemba Medika, 
Jakarta, 2008

Bardu, Tito Y. S., Perbandingan EfektifitasTepid Sponging Dan Plester Kompres Dalam Menurunkan Suhu Tubuh Pada Anak Usia Balita Yang Mengalami Demam Di Puskesmas Salaman 1 Kabupaten Magelang,Skripsi, Magelang, 2014, diperoleh Tanggal 14 Mei 2015 dari http://perpusnwu.web.id/karyailmiah /documents/3589.pdf

Dagoon, et al, RBS Technology, LivelihoodEducation and Life Skills Series Home Economics Tekhnology IV,Rex Book Store, Philipina, 2007

Dahlan, Muhamad S, Statistik

UntukKedokteran dan

Kesehatan:Deskriptif, Bivariat, danMultivariat,Dilengkapi denganMenggunakanSPSS, SalembaMed ika, Jakarta, 2013

Debora, Oda, Proses Keperawatan

DanPemeriksaan

Fisik,SalembaMedika, Jakarta, 2011

Dempsey, P. N., \& Arthur D. D., RisetKeperawatagn: Buku Ajar \& Latihan, EGC, Jakarta, 2002

Dinas Kesehatan Provinsi Lampung,Laporan Data Kesakitan SP2TP tahun 2013, Bandar Lampung, 2014

Djuwariah, Sodikin, \& Mustiah Yulistiani,Efektivitas Penurunan Suhu Tubuh Menggunakan Kompres Air Hangat dan Kompres Plester Pada Anak dengan Demam di Ruang Kanthil RSUD Banyumas, Skripsi,Banyumas, 2011, diperoleh tanggal 20 Januari 2015, dari http://digilib.ump.ac.id/files/disk1/ 16/ihptump-a-djuwariyah-758-1- efektivi-.pdf

Dorland, W. A. Newman, KamusKedokteran Dorland, EGC, Jakarta,2010

Febri, Ayu Bulan \& Zulfitro Marendra,Smart Parents Pandai MengaturMenu \&Tanggap Saat Anak Sakit, Gagasmedia, Jakarta, 2010

Guyton, A. C., \& John E. Hall, Buku AjarFisiologi Kedokteran, EGC,Jakarta, 2007

Hamid, Mohammad Ali, Keefektifankompres tepid sponge yang dilakukan ibu dalam menurunkan demam pada anak: Randomized Control Trial Di puskesmas Mumbulsari Kabupaten Jember,Skripsi, Universitas Sebelas Maret Surakarta, 2011, diperoleh tanggal 20 Januari 2015, dari

http://eprints.uns.ac.id/7020/1/2112 11812201107501.pdf

Hidayat, Aziz Alimul, Pengantar IlmuKeperawatan Anak 1, SalembaMedika, Jakarta, 2005

Hidayat, A. Aziz Alimul, Pengantar IlmuKesehatan Anak Untuk PendidikanKebidanan,Salemba Medika,Jakarta, 2008

Hidayati, R., dkk, Praktik LaboratoriumKeperawatan Jilid 1, Erlangga,Jakarta, 2014

Inawati, Demam Typhoid, FK-Universitas Wijaya Kusuma Surabaya, 2008, dipeoleh tanggal 4 Februari 2015, dari http://elib.fk.uwks.ac.id/asset/archi eve/jurnal/Vol\%20Edisi\%20Khusu s\%20Desember\%202009/DEMAM \%20TIFOID.pdf

Ismoedijanto, Demam Pada Anak, FK-UNAIR, Surabaya, 2000, dari http://saripediatri.idai.or.id/pdfile/2 -2- 
6.pdf

Isneini, Memed, Efektifitas PenurunanSuhu Tubuh Antara Kompres Hangat Dan Water Tepid Sponge Pada Pasien Anak Usia 6 Bulan - 3 Tahun Dengan Demam Di Puskesmas Kartasura

Sukuharjo,Sukuharjo, 2014, diperoleh tanggal 14 Mei 2015 dari http://eprints.ums.ac.id/32263/24/2. \%20NASKAH\%20PUBLIKASI\%20FUL\%2 OTEX.pdf

Jaypee, Basic Concepts On NursingProcedures, I Clement, India, 2007

Kania, Nia, penatalaksanaan Demam PadaAnak, Bandung, 2007, dari http://pustaka.unpad.ac.id/wpconte nt/uploads/2010/02/penatalaksanaa $n$ demam pada anak.pdf

Maharani, Lindya, perbandingan efektifitaspemberian kompres hangat dan tepid water sponge terhadap penurunan suhu tubuh balita yang mengalami demam di Puskesmas Rawat Inap Karya Wanita Rumbai Pesisir, Skripsi, Universitas Riau,2011, diperoleh tanggal 20 Januari 2015, dari https://www.scribd.com/doc/73195 543/all-ok

Maling, Sri \& Syamsul, Pengaruh KompresTepid Sponge Hangat Terhadap Penurunan Suhu Pada Anak Umur 1 - 10 Tahun Dengan Hipertermia Di RSUD Tugurejo Semarang,Semarang, 2012, diperoleh tanggal 14 Mei 2015 dari http://180.250.144.150/ejournal/index.php/ilmukeperawatan/a rticle/download/85/112

Notoatmodjo, Soekidjo,Metodologipenelitian Kesehatan, Rineka Cipta,
Jakarta, 2012

Permatasari, Sri \& Muslim,

PerbedaanEfektifitas Kompres Air

Hangat Dan Kompres Air Biasa

Terhadap Penurunan Suhu Tubuh Pada Anak Dengan Demam Di RSUD Tugurejo Semarang, Semarang, 2013, diperoleh Tanggal 14 Mei 2015 dari http://ejournal.stikestelogorejo.ac.id/ e-

journal/index.php/ilmukeperawatan/a rticle/download/126/151

Potter, P. A., \& Perry, A. G., Buku ajarfundamental keperawatan : konsep, proses, dan praktik ( $4^{\text {th }}$ ed. Vol. 1$), \mathrm{EGC}$, Jakarta, 2005

Potter, P. A., \& Perry, A. G., FundamentalKeperawatan, Edisi 7 Buku 2,Salemba Medika, Jakarta, 2010

Purwanti, Sri, Pengaruh Kompres HangatTerhadap Perubahan Suhu Tubuh Pasien Anak Hipertermi di RSUD Dr. Moewardi Surakarta. Surakarta, Skripsi, Surakarta, 2008, diperoleh tanggal 19 Januari 2015, dari http://publikasiilmiah.ums.ac.id/bit stream/handle/123456789/484/2f.p df?sequence $=1$

RSUD dr. H. Abdul Moeloek Provinsi Lampung, Data Penyakit RuangAlamanda Tahun 2014, RSUD dr.H. Abdul Moeloek, Bandar Lampung, 2014

Said, Perbedaan Pengetahuan Ibu SebelumDanSesudahDiberikanPenyuluh anTentang PenagananAnak Dengan Demam Panas DiWilayah Kerja PuskesmasManggala Kabupaten TulangBawang Tahun 2014, Skipsi, PSIKUniversitas Malahayati, 2014 
Saryono, \& Mekar D. A., MetodologiPenelitian Kualitatif dan Kuantitatifdalam Bidang Kesehatan, NuhaMedika, Yogyakarta, 2013

Setiawati, Pengaruh tepid sponge terhadappenurunan suhu tubuh dan kenyamanan pada anak usia pra sekolah dan sekolah yang mengalai demam di ruang perawatan anak Rumah Sakit Muhammadiyah Bandung tahun 2009, Skripsi,Universitas Indonesia Fakultas IImu Keperawatan, 2009, diperoleh tanggal 19 Januari 2015, dari http://www.digilib.ui.ac.id.

Setyowati, Lina, Hubungan TingkatPengetahuan Orang Tua Dengan Penanganan Demam Pada Anak Balita Di Kampung Bakalan Kadipiro Banjarsari Surakarta,Skripsi, STIKES PKU Muhamadiah Surakarta, 2013, dari http://stikespku.com/digilib/files/di sk1/1/stikes\%20pku--linasetyow- 44-120101292.pdf

Sherwood, Lauralee, Fisiologi Manusia :Dari Sel Ke Sistem Ed. 8, EGC,Jakarta, 2014

Siswanto dkk, Metodologi PenelitianKesehatan dan Kedokteran, Bursallmu, Yogyakarta, 2013

Sodikin, Prinsip Perawatan Demam PadaAnak, Pustaka Belajar, Yogyakarta,2012

Sudoyo, dkk, Buku Ajar Ilmu PenyakitDalam jilid III, Departemen IImuPenyakit Dalam FK-Universitas Indonesia, Jakarta, 2006

Sugihartiningsih, Efektifitas KompresTepid Sponge Terhadap Penurunan Suhu Tubuh Anak Dengan Demam Di RS PKU Muhammadiyah Surakarta, Surakarta, 2014,diperoleh tanggal 14 Mei 2015 dari

http://eprints.ums.ac.id/32263/24/2.
\%20NASKAH\%2OPUBLIKASI\%20FUL\%2

OTEX.pdf

Suriadi, \& Rita Y., Asuhan KeperawatanPada Anak, Sagung Seto, 2010

Tambunan, Eviana S., \& Deswani Kasim,Panduan Pemeriksaan Fisik BagiMahasiswa Keperawatan, SalembaMedika, Jakarta, 2011

Thomas, S., Vijaykumar, C., Naik, R., Mose P. D., \& Antonisamy, B.,Comparative effectiveness of tepid sponging and antipyretic drug versus only antipyretic drug in the management of fever among children: a randomized controlled trial. Indian Pediatrics, 46(2): 133-136, 2009, diperoleh tanggal 19 Januari 2015, dari http://www.indianpediatrics.net/feb 2009/133.pdf

Uliyah, Musrifatul, \& A. Aziz A. H.,PraktikumKeterampilan DasarPraktik KlinikAplikasi DasardasarPraktikKebidanan,SalembaMedika , Jakarta, 2008

Wahyuni, Perbedaan Efek TeknikPemberian Kompres Hangat Pada Daerah Axilla Dan Dahi Terhadap Penurunan Suhu Tubuh Pada Klien Demam di Ruang Rawat Inap RSUP DR Wahidin Sudirohusodo Makasar tahun 2009, Skipsi,Universitas Hasanudin Makasar, 2009, diperoleh tanggal 20 Januari 2015, dari

http://www.4shared.com/document /FB9xzrKp/lka Skripsi.html

Widjaja, M. C., Mencegah dan mengatasidemam pada balita ( $1^{\text {th }}$ ed.), KawanPustaka, Jakarta, 2001 